\title{
Extended Release Patch Dosage Form
}

National Cancer Institute

\section{Source}

National Cancer Institute. Extended Release Patch Dosage Form. NCI Thesaurus. Code C42923.

A patch designed to release active and/or inert ing redient(s) at a controlled, prolonged rate so as to reduce dosing frequency. 